\title{
Vaccine-induced tumor regression requires a multi-step cooperation between T cells and myeloid cells at the tumor site
}

\author{
Maxime Thoreau', Hwei Xian Leong Penny ${ }^{2}$, Kar Wai Tan², Fabienne Regnier', Julia Miriam Weiss', Bernett Lee², \\ Ludger Johannes ${ }^{3}$, Estelle Dransart ${ }^{3}$, Agnes Le bon ${ }^{1}$, Jean-Pierre Abastado ${ }^{2}$, Eric Tartour ${ }^{4}$, Alain Trautmann? \\ Nadege Bercovici ${ }^{1 *}$
}

From 30th Annual Meeting and Associated Programs of the Society for Immunotherapy of Cancer (SITC 2015) National Harbor, MD, USA. 4-8 November 2015

\begin{abstract}
Most cancer immunotherapies under present investigation are based on the belief that cytotoxic $\mathrm{T}$ cells are the most important anti-tumoral immune cells, whereas intratumoral macrophages would rather play a protumoral role. We have challenged this antagonistic point of view and searched on the contrary for complementary contributions provided by tumor-infiltrating $\mathrm{T}$ cells and macrophages, reminiscent of those observed in anti-infectious responses. We demonstrate that, in a model of therapeutic vaccination, cooperation between myeloid cells and $\mathrm{T}$ cells is indeed required for tumor rejection. Vaccination elicited an early rise of $\mathrm{CD} 11 \mathrm{~b}^{+}$myeloid cells that preceded and conditioned the intratumoral accumulation of $\mathrm{CD} 8^{+}$ $\mathrm{T}$ cells. Conversely, $\mathrm{CD} 8^{+} \mathrm{T}$ cells and IFNg production activate myeloid cells and were required for tumor regression. A 4-fold reduction of $\mathrm{CD}^{+}{ }^{+} \mathrm{T}$ cell infiltrate in CXCR3KO mice did not prevent tumor regression, whereas a reduction of tumor-infiltrating myeloid cells significantly interfered with vaccine efficiency. We show that macrophages from regressing tumors can eliminate tumor cells by TNF $\alpha$ release and phagocytosis. Altogether, our data suggest new strategies to improve the efficiency of cancer immunotherapies, by promoting intratumoral cooperation between macrophages and $\mathrm{T}$ cells.
\end{abstract}

\section{Authors' details}

'Institut Cochin, Inserm U1016, CNRS UMR8104, Univ. Paris Descartes, Sorbonne Paris Cité, Equipe labellisée "Lique contre le Cancer", Paris, France.

${ }^{2}$ Singapore Immunology Network, BMSI, A-STAR, Singapore, Singapore.

IInstitut Cochin, Inserm U1016, CNRS UMR8104, Univ. Paris Descartes, Sorbonne Paris Cité, Equipe labellisée "Ligue contre le Cancer", Paris, France Full list of author information is available at the end of the article
${ }^{3}$ Institut Curie, INSERM U1143, CNRS UMR3666, Paris, France. ${ }^{4}$ Inserm U970, PARCC, Université Paris Descartes, Sorbonne Paris Cité, Paris, France.

Published: 4 November 2015

doi:10.1186/2051-1426-3-S2-P293

Cite this article as: Thoreau et al:: Vaccine-induced tumor regression requires a multi-step cooperation between $T$ cells and myeloid cells at the tumor site. Journal for ImmunoTherapy of Cancer 2015 3(Suppl 2):P293.
Submit your next manuscript to BioMed Central and take full advantage of:

- Convenient online submission

- Thorough peer review

- No space constraints or color figure charges

- Immediate publication on acceptance

- Inclusion in PubMed, CAS, Scopus and Google Scholar

- Research which is freely available for redistribution

Submit your manuscript at www.biomedcentral.com/submit
() Biomed Central 